\title{
THE RELATIVE TREATMENT OF SECURITIES IN RAIIROAD REORGANIZATIONS UNDER SECTION 77
}

\author{
Henry J. Friendly* and Lingan M. Tondel, JR. $\dagger$
}

The problems as to the recognition to be accorded the relative rights of security holders in pending railroad bankruptcies are the most complex that have arisen since the decision in the Boyd case ${ }^{1}$ focused attention on this phase of reorganization law. This is due not merely to the number of railroads involved, ${ }^{2}$ but to the intensity of their financial difficulties.

The typical railroad reorganization of the 1914-1930 period was, by present standards, not severe. Usually it was carried out through foreclosure of a junior mortgage constituting a general lien upon the bulk of the property of the carrier. Underlying liens, whether divisional or system in character, were commonly left undisturbed. The necessary reduction in fixed charges was accomplished through the exchange of the bonds secured by the mortgage under foreclosure, partly or wholly, for other types of securities-income bonds or preferred or common stock. Then, as now, it was usually necessary to raise funds for rehabilitation of the property and reorganization expenses. Funds were also required for the payment of dissenters. Since underlying liens were normally not foreclosed, it was impracticable to raise these funds by the sale of bonds secured by a first mortgage. New money was obtained by offering to stockholders, on payment of an "assessment," certain of the same rank of securities as went to satisfy 'creditors' claims, as well as stock in the reorganized company. In order to give stockholders an inducement to pay the "assessment," this was fixed at a figure somewhat less than the estimated market value of the entire package of new securities offered. Under these circumstances, the Boyd doctrine required that a "fair offer" of participation should also be made to all creditors. Hence, the reorganization plan offered something to every class of security holders, although, in

*A.B., I923, LL.B., 1927, Harvard University. Member of the New York Bar. Member of firm of Root, Clark, Buckner \& Ballantine. Author of The Historic Basis of Diversity Jurisdiction (I928) 4 I HaRv. L. Rev. 483 , Some Comments on The Corporate Reorganizations Act (1934) 48 HaRv. L. Rev. 39, and The 1935 Amendment of the Railroad Reorganization Act (1936) 36 CoL. L. REv. 27.

+A.B., I933, University of Washington; LL.B., I936, Harvard University. Member of the New York Bar. Associated with firm of Root, Clark, Buckner \& Ballantine. Author of Venue under the Corporate Reorganizations Act (1936) 20 MrNv. L. REv. 506, and Corporations Eligible for Relief Under Section $77 B$ (r937) 21 MINN. L. REv. 144.

1 Northern Pacific Ry. v. Boyd, 228 U. S. 482 (rgr3).

${ }^{2}$ On July 3I, I939, ro8 railroads operating 76,703 miles of road, or $30.70 \%$ of the entire railroad mileage of the country, were in receivership or trusteeship. I. C. C., 53d ANN. REP. (I939) 20. 
the case of stockholders, and occasionally in that of unsecured creditors, continued participation in the enterprise was dependent on supplying new money. ${ }^{3}$

The central legal question in these reorganizations was the extent to which this right to retain a stake in the enterprise might properly be accorded to stockholders. Decisions as to the relative rights of creditors were few and far between..$^{5}$ Indeed, a Circuit Court of Appeals had held that this was not a subject with which equity was concerned. ${ }^{\circ}$

In the past decade, the decreased earnings of the railroads, not mercly in dollar amount but in relation to their gross revenues, and the consequent sensitivity of net railway operating income to declines in traffic or in rates or to increases in expenses, have compelled reorganizations cutting much more deeply into capital structures.? This has often required partial or total elimination of the fixed charge on senior bonds. ${ }^{8}$ The general impairment of railroad credit has made it impracticable to raise new money except by the sale of senior securities ranking ahead of, or, at least, along with the best bonds issued in the reorganization. The destruction of the interest of the stockholders, both economically and market-wise, has removed them, in most cases, as potential sources of new money, and frequently the Reconstruction Finance Corporation has been looked on to provide these funds.

This change in the economic situation has been paralleled, at least so far as concerns the proceedings conducted under Section 77 of the Bankruptcy Act, by an increase in the responsibility of the courts and the Commission for safeguarding the relative rights of security holders. In the past, equity courts had been invited to

- Reorganizations to which the foregoing description would generally apply are the Wabash reorganization of 1915, the Missouri Pacific and Chicago, Rock Island and Pacific reorganizations of 1917, and the Milwaukce reorganization of 1027. On the other hand, the Pere Marquene and the St. Louis and San Francisco Railroad reorganizations of 1916 reached down to substantially all of the underiying and divisional liens.

"The leading cases were Louisville Trust Co. v. Louisville, N. A. \& C. Ry., 174 U. S. 674 (1899); Northern Pacific Ry. v. Boyd, 228 U. S. 482 (1913); Guaranty Trust Co. v. Missouri Pac. Ry., 238 Fed. 812 (E. D. Mo. 1916); North American Co. v. St. Louis \& S. F. Ry., 246 Fed. 260 (E. D. Mo. 1916); Kansas City Ry. Co. v. Central Union Trust Co., 27 I U. S. 445 (1926); Jameson v. Guaranty Trust Co., 20 F. (2d) 808 (C. C. A. 7 th, 1927), cert. denied, 275 U. S. 569 (1927).

* Guaranty Trust Co. v. Missouri Pac. Ry. Co.; Jameson v. Guaranty Truist Co., both supra note 4.

- New York Trust Co. v. Contirental \& Commercial etc. Bank, 26 F. (2d) 872 (C. C. A. 8th, I928), cert. denied, 278 U. S. 644 (1928).

The ratio of net railway operating income to gross operaing revenues of all Class I railroads fell from $32.4 \%$ in 1900 and $30.4 \%$ in 1905 to $10.4 \%$ in $1932,16.5 \%$ in 1936 , and $14.1 \%$ in 1937 . Fifteen Percent Case, 1937-1938, 226 I. C. C. 41, 59 (1938). Exhibit 4 in this case, prepared by Mr. Fairman R. Dick of New York City, showed, at page 23, that 7 major roads in receivership in the 1890 's had a spread of $31.7 \%$ between gross revenues and expenses (including rents and taxes) and were reorganized with fixed charges equal to $22.8 \%$ of revenues, whereas 20 roads in receivership or bankruptcy in the fiscal year ended June 30,1937 , had 2 spread of only $9.6 \%$ between gross revenues and expenses, 2s compared with pre-receivership fixed charges of $17.9 \%$ of revenues. In other words, the pre-receivership fixed charges of the roads now undergoing reorganization took considerably less of the shipper's dollar than the post-receivership fixed charges of the 1890 's, but the spread between revenues and expenses was only a third of that in the earlier period.

Examples are the Milwauke General Mortgage $4 \%$ bonds and the Western Pacific First-Mortgage $5 \%$ bonds of 1946. Chicago, M., St. P. \& P. R. R. Reorg., Fin. Doc. No. 10882 (Feb. 12, 1940), mimeo. rep. at 133-135, mod. (June 4, 1940); Western Pac. R. R. Reorg., 230 I. C. C. 61, 64, 101 (1938), 233 I. C. C. 409,417 (1939). 
scrutinize the fairness of plans primarily in an endeavor to secure immunity from the Boyd doctrine by obtaining a judicial pronouncement that a "fair offer" had been made to junior creditors. ${ }^{9}$ The Commission was brought into the situation only when the proceedings had reached an advanced stage. ${ }^{10}$ Even then the Commission was concerned only with the public interest involved, and displayed little solicitude as to allocations between classes of security holders. ${ }^{11}$ Under Section 77 , on the other hand, the Commission and the courts are specifically required to find that a plan "is fair and equitable, affords due recognition to the rights of each class of creditors and stockholders, does not discriminate unfairly in favor of any class of creditors or stockholders, and will conform to the requirements of the law of the land regarding the participation of the various classes of creditors and stockholders." 12 Whether or not the Boyd doctrine applies in its technical sense as between classes of creditors, ${ }^{13}$ the language of the statute requires recognition of all differences in status, not only between creditors and stockholders, but also between underlying bondholders, on the one hand, and the holders of junior bonds or unsecured claims, on the other. ${ }^{14}$.

\section{General Principles Governing Distribution}

At the very beginning of the performance of its tasks under Section 77, the Commission was confronted with a claim that, far from extending the Boyd doctrine, Section 77 had repealed it. The so-called "composition" theory, evolved by counsel representing debtor interests, was that Section 77 differed from the previous equity procedure in being a "composition" statute; that the very basis of a composition was that the debtor retained an interest in his property; and that a composition to which the requisite proportion of the creditors had assented could not be upset by the courts because of unduly lenient treatment of the equity interests unless the creditors had failed to receive as much as they would have received on a liquidation basis. ${ }^{15}$ This

\footnotetext{
- See Swaine, Reorganization of Corporations: Certain Developments of the Last Decade, in Some Lear. Phases of Corporste Fisiscisc, Reorganization and Reguration (1951) 133, 142 ff.

${ }^{10}$ Interstate Commerce Act $\$ 200,49$ U. S. C. $\$ 202$. See dissent of Commissioner Eastman in Chieago, M. \& St. P. R. R. Reorg., 131 I. C. C. 673, gor (1928).

${ }^{12}$ Securities of C. \& E. 1. Ry., 67 I. C. C. 6r, 64, (1921); Chicago, M. \& St. P. R. R. Reorg., supra note ro. See Reorganization of A, B. \& A. Ry, I17 I. C. C. I8r, 185 (1926) ("Our principal concern is witt the future of $\Lambda, B$. \& $A$. property as 2 transportation facility." ).

${ }^{12} 577(\mathrm{c})$.

${ }^{12}$ This has been much discussed. See Swaine, supra note 9, at 142; Frank, Some Realistic Refiections on Some Aspects of Corporation Reorganization (1933) I9 VA. L. Rev. 54x, 553-60; New York Trust Co. v. Continental \& Commercial ete. Bank, supre note 6.

14 Both the Commission and the courts have consistently so held. See New York, N. H. \& H. R. R. Reorg. Fin. Doc. No. I0992 (March 22, 1940) mimeo. rep. at 106; Chieago G. W. R. R. Reorg., 228 I. C. C. 585, 623 (1938); Western Pac. R. R. Reorg., 23u I. C. C. 61, 100 (1938); and Missouri P. R. R. Reorg., 239 I. C. C. 7, 104 (1940); In re N. Y., N. H. \& H. R. R., 16 F. Supp. 504, 509 (D. Conn. 1936); In re Chicago \& N. W. Ry., 88 F. Supp. 932, 935 (N. D. Ill. 1936). The Commission has properly given no weight to the omission from the statute as enacted of the words "in the order of their seniority" contained in H. R. 6249. Sce Moore, Railroad Fixed Charges in Bankruptcy Proceedings (1939) 47 J. Poz. Ecox. 100, 117 . But of. St. Louis-S. F. Ry. Reorg., Fin. Doc. No. 10008 (July 6, 1940) mimeo. rep. 2t 78-79.

${ }^{18}$ See, e.g., Brief for Debtor (May 22, 1937) Chicago \& E. I. Ry. Reorg., Fin. Doc. No. 9952.
} 
theory received short shiift both from the Commission ${ }^{16}$ and from at least one lower court, ${ }^{17}$ even before the Supreme Court administered the coup de grâce in the Los Angeles Lumber Products case. ${ }^{18}$

While it is easy to say what theory the Commission rejected, it is not so easy to define precisely the theory that has been adopted. The Commission has not purported to lay down any neat formula for universal application. Rather it has followed common law tradition wherein "lines are pricked out by the gradual approach and contact of decisions on the opposing sides."18

However, two general statements may be ventured with some assurance. In the first place, the Commission purports to adhere to a principle of absolute priority, not only as between creditors and stockholders, but also as between classes of creditors. Once a hierarchy of interests is established, each class must receive 100\% satisfaction before the next lower class may participate at all. The claim thus satisfied includes, in the case of creditors, interest as weil as principal. ${ }^{20}$ However-and this is a vitally important corollary-100\% satisfaction is deemed to be given by $100 \%$ satisfaction in paper. Priorities are considered satisficd if the full amount of the claim is recognized in securities of the appropriate dollar amount. ${ }^{21}$ No attempt has been made to insist that the securities issuable to a senior class must have a prospective market value of roo cents on the dollar before a junior class may participate. Indeed, in those few instances where senior interests have asked for more than $100 \%$ in new securities to compensate for sacrifices entailed in receiving partial.compensation in income bonds or stock, such treatment has been denied. ${ }^{22}$

${ }^{10}$ Chicago \& E. I. Ry. Reorg., 230 I. C. C. 199, 233-234 (1938); Akron, C. \& Y. Ry. and Northern O. Ry. Reorg., 228 I. C. C. 645, 675 (1938); Denver \& R. G. W. R. R. Reorg, 233 I. C. C. $515,578-579$ (1939); Missouri P. R. R. Rearg., 239 I. C. C. 7, 132-133 (1940); Chicago, M., St. P. \& P. R. R. Reorg, supra note 8 , at 148 ; see also note $I 4$, supra.

${ }^{27}$ In re Chieago G. W. R. R., 29 F. Supp. I49 (N. D. Ill. 1939).

${ }^{18}$ Case v. Los Angeles Lumber Products Co, to Sup. Ct. I (1939). See Dodd, The Los Angeles Lumber Products Company Case and Its Implications (1940) 53 Hakv. L. Rev. 713, 7rg. An attempt may now be made to resuscitate this doctrine in certain cases as a result of Mr. Justice Stone's statement in S. E. C. v. U. S. Realty \& Improvement Co, 60 Sup. Ct. 1044, 1052 (1940): "In cases where subordinate creditors or the stockhoiders are the managers of its business, the preservation of going-concern value through their continued management of the business may compensate fer reduction of the claims of the prior creditors without alteration of the managenent's interest, which would otherwise be required by the Buyd case." Was this intended to be limited to Chapter XI proceedings? What is meant by "the stockholders"? What guaranties as to the management's continuance must be offered? One may venture the prediction that lower courts will be obliged to listen to thousands of hours of argument before this dictum is finally clarified.

10 Mr. Justice Holmes in Noble State Bank v. Hastell, 219 U. S. 104, 112 (xgrr).

${ }^{20} \mathrm{Sec}$, e.g., Spokane International Ry. Reorg., 228 I. C. C. 387,402 (1938); Chicago G. W. R. R Reorg., 228 I. C. C. 585,618 (1938); Denver \& R. G. W. R. R. Reorg., 233 I. C. C. 515, 574 (1939); Missouri P. R. R. Reorg., 239 I. C. C. 7, 116 (1940); Chicago, Mf., St. P. \& P. R. R. Reorg., supra note 8, 2t I24. Where the contract rate exceeds current interest rates, the former is recognized up to matunty or the effective date of the exchange. Chicago G. W. R. R. Reorg., 228 I. C. C. 585, ur6 (1938). After maturity a rate of $4 \%$ has been approved. Chicago \& E. 1. Ry. Reogg., 230 I. C. C. 199, 235 (1938). See also St. Louis-S. F. Ry. Reorg., supra note 14 , at $67,75-76$.

${ }^{22}$ See Chicago G. WV. R. R. Reorg., 228 I. C. C. 585,623 (1938) (bondholders' priority preserved by 2ward of " 100 percent of priscipal and interest in some form of new securities, prior to the recognition of subordinate classes" (italies added)).

${ }^{12}$ See Brief for Group of Institutional Investors (May 28, 1938) p. 73, and decision in Chicago, Malwaukec, St. P. \& P. R. R. Reorg., supra note 8, at $153-135$, 141. In Chicago \& N. W. Ry. Reorg, 
The Commission has even gone further. It has not insisted upon allocations which would reasonably assure that the securities issuable to senior interests should attain a market value of 100 cents on the dollar before any income of the reorganized company could be paid to junior interests. An example will clarify what is meant. Suppose that certain bondholders are to receive $40 \%$ of their claim in $4 \%$ fixed-interest bonds, $30 \%$ in $41 / 2 \%$ income bonds, and $30 \%$ in $\$ 5$ preferred stock, whereas stockholders receive only common stock. While the market value of the package of securities issued to the bondholders would not be anything like par within any reasonably foreseeable time after the reorganization, the allocation is such that when, if ever, it should become possible to pay dividends on the common stock issued to the existing stockholders, the market value of the package of securities awarded to the bondholders would probably then be such as to enable them to get out whole. On the other hand, suppose a case where a senior interest receives $40 \%$ in income bonds, $30 \%$ in preferred and $30 \%$ in common stock, and a junior interest also receives common stock, although in a smaller amount per dollar of claim. Here the junior interest may receive some income on the reorganization securities issued to it at a time when the market value of the securities issued to the senior interest would still be far from par. Yet the Commission has sustained provisions of this type. ${ }^{23}$ In other words, the Commission believes that priorities may be sufficiently recognized by a quantitative as distinguished from a qualitative preference, provided that the junior interest does not receive a security ranking prior to the lowest security issued to the senior interest and receives even that lowest security on a less favorable basis.24 Just how much less favorable the basis must be is a matter of judgment, the reasoning behind which is normally not fully disclosed.

The matter may be put in another way. The Commission anticipated the decision in the Los Angeles Lumber Products Company case that a class of stockholders whose interest is "valueless" may not be accorded a share in the reorganized enterprise even if the creditors assent, and has applied this principle not only to stockholders $^{25}$ but also to unsecured creditors. ${ }^{26}$ On the other hand, if the interest of a

236 I. C. C. 575,635 (2939), a similar suggestion was rejected. There was ample precedent for the treatment requested, 25, for example, in the highly successful Atchison rcorganization of 1895 . The diffeulty is that this form of treatment leads either to inflation of the capital structure or to radical limitation of the interests allowed to participate in the plan.

${ }^{23}$ Louisian \& N. W. R. R. Reorg., 224 I. C. C. 58, 74-75 (1937), mod., 230 I. C. C. 171 (1938); Chicago \& E. I. Ry. Reorg, 230 I. C. C. 199 (1938); Chicago G. W. R. R. Reorg., 228 I. C. C. " 585 (1938), mod., 233 1. C. C. 63 (1939); Denver \& R. G. W. R. R. Reorg., 233 I. C. C. 515,589 (1939); Chicago, M., St. P. \& P. R. R. Reorg., supre note 8; Erie R. R. Rcorg., Fin. Doc. No. 11915 (April 6, 1940).

In the Chicago Great Western case, the Commission sought (p. 623) to justify this method of allocation by pointing out that if interest on the income bonds and dividends on the preferred stock were paid, the existing bondholders would actually receive on the principal amount of their claim more than the $4 \%$ contract rate of interest on their bonds. However, as a practical matter, very few bondholders would rega:d this chance of increased income as compensatory. But of. Dodd, supra note 18, at 741-743.

"' For a clear statement of this principle, see Missouri P. R. R. Reorg., 239 I. C. C. 7, 126-127 (1940).

${ }^{25}$ The Commission wiped out all stock interests in the Spoliane International, Oregon, Pacific \& Eastern, Chicago \& North Western, Denver \& Rio Grande Western, Milwaukec, New Haven, Missouri Pacific (exceps for stock in the New Orleans, T. \& M. Ry., found to have some value), Western Pacific, 
particular class of stockholders or creditors is found to have "value," the Commission permits this junior interest to retain a share in the reorganized enterprise, even though there is scant probability that the securities issuable to senior creditors will ever have a market value equal to the amount of their claim, and this participation may even be in the same type of security as is issuable to senior claimants.

Strong practical considerations support this course, for, if the interest of a particular class of security holders has "value," their vote must usually be obtained upon the plan, ${ }^{27}$ and there is little chance that a class of security holders would approve a plan utterly excluding them. However, it is well to realize how different this practice is from the rule applicable between mortgagee and mortgagor outside the reorganization field. There the Supreme Court has held that not merely principles of equity but the due process clause forbid infringement of the creditors' right to insist upon full payment before giving up any of their security. ${ }^{28}$

So much for the principles underlying the Commission's treatment of priorities. Let us now turn to their application.

Kansas City, Kaw Valley \& Western, and Savannah \& Atlanta proceedings. Stockholders were allowed a very much deflated interest in Louisiana \& N. W. R. R. Reorg., 224 I. C. C. 58,75 (1937), mod., 230 I. C. C. 171, 175 (1938). In the Chicago Great Western and Chicago \& Eastern lllinois.proceedingt preferred but not conmon stockholders were allowed to participate. The only major railroad all of whose stockholders retain some interest under the approved plan is the Erie, where the preferred had a preference only as to dividends. Infra note 32 .

The Commission has generally refused to heed arguments that the business value of preserving the stock interest of another railroad justified better treatment than would have been awarded otherwise. Sce, e.g., Chicago \& E. I. Ry. Reorg., 230 I. C. C. 199, 234-235 (1938); cf. Chicago, I. \& L. Ry. Reorg., 233 I. C. C. 335,349 (1939). But of. Spokane Interal. Ry. Reorg., 233 I. C. C. 157, 158, 166-168 (1939).

In many cases stockholders, pointing particularly to the reference in $\$ 77(b)(3)$, have strenuously urged that they should at least be given warrants to purchase stock in the reorganized company. Their contentions were rejected in Chicago \& N. W. Ry. Reorg., 236 I. C. C. 575, 637-638 (1939); In re Chicago Great Western R. R., 29 F. Supp. 149, 160 (N. D. 1ll. 1939); Missouri P. R. R. Reorg., 239 I. C. C. 7, 132-133 (19-40). Miller, C., dissenting, urged the issue of warrants in Chicago, M., St. P. \& P. R. R. Reorg., supra note 8, at 158; New York, N. H. \& H. R. R. Reog., supra note I4, at 174. See note 34, infra.

It is somewhat difficult to reconcile with these holdings the results under Chapter $X V$ where, in the two plans thus far approved by the statutory courts, stockholders have been treated relatively well, although secured creditors have been forced to make substantial concessions. In re Baltimore \& Ohio R. R., 29 F. Supp. 608 (D. Md. 1939), cert. denied, 60 Sup. Ct. 470 (1940); In re Montana, W. \& S. R. R, 32 F. Supp. 200 (D. Mont. 1940). Section 725(3) of Chapter XV requires the court to find "that the plan is fair and equitable as an adjustment, affords due recognition to the rights of cach class of creditors and stockholders and fair consideration to each class thereof adversely affected, and will conform to the law of the land regarding the participation of the various classes of creditors and stockholders." Since S. E. C. v. U. S. Realty \& Improvement Co, 60 Sup. CL. 1044 (1940) holds that the words "Fair and equitable" in Chapter XI have the same meaning as in Chapter X, it would seem that the quoted words in Chapter XV have the same meaning as in Section 77, unless the phrase "2s an adjustment" is sufficient to lead to a different result. Cf. Mahaffe; C., dissenting (Eastman, C., concurring) in Montana, W. $\mathrm{S}$. R. R. Fin. Adjustment, 236 1. C. C. 325,338 (1939).

24 See Savannah \& Atlanta Ry. Reorg., 224 I. C. C. 197, 216 (1937); Spokane International Ry. Roorg., 228 I. C. C. 387,402 (1938); Western Pac. R. R. Reorg., 230 I. C. C. 61, ror (1938); Oregon, P. \& E. Ry. Reorg, 233 I. C. C. 187 , 194 (1939); Kansas City, R. V. \& W. R. R. Reorg., 236 I. C. C. 137, 139 (1939) (on reference back from the court); Missouri P. R. R. Reorg., 239 I. C. C. 7, 129 (1940) (seneral unsecured claims against a subsidiary debtor found valueless); St. Louis-S. F. Ry. Reorg., supre note 14 , at 71. Cf. Chicago, I. \& L. Ry. Reorg., 233 I. C. C. 335, 349 (1939).

27 $577(\mathrm{c})$.

28 Louisville Joint Stock Land Bank v. Radford, 295 U. S. 555, 579 (1935); Wright v. Vinton Branch, 300 U. S. 110 (1937). 


\section{Determination of the Classes Entitled to Participate}

The initial problem is the ascertainment of the classes of security holders entitled to participate in some form in the reorganized company. ${ }^{29}$ Here the critical question is whether the interest of a particular class of security holders has "value."

The answer to that question follows from the Commission's judgment as to the total capitalization to be permitted. This is determined on the basis of a review of valuation and investment data and past and prospective earnings, a subject discussed in another article in this issue. ${ }^{30}$ The Commission then suburacts from this total the securities left undisturbed and those to be issued for new money. There are next deducted the claims of secured creditors, with accrued interest to the effective date of the reorganization, and, if the available total permits, the claims of unsecured creditors, also with accrued interest. If any securities are still available, stockholders are allowed to participate. Preferred stock has been recognized to the exclusion of common, ${ }^{31}$ except where, as in the Erie reorganization, the preference of the preferred stock extended only to dividends. ${ }^{32}$ When the permissible capitalization of the reorganized company is exhausted, the interest of a class not yet reached is said to be "valueless," and that class and all classes junior to it are excluded.

\section{Distribution as Between Senior and Junior Interests}

The Commission is then faced with the problem of allocating the reorganization securities among the classes which it has found entitled to participate. Solution of this problem is necessarily conditioned by the type of securities available. The exacting task of accurately reflecting priorities has been made still more difficult because of

s" There are of course the even more basic problems of the validity and amounts of claims, their relative priorities and their classification, as to which the Commission, under 377 (c)(7), accepts and follows the court's decision. Kansas City, K. V. \& W. R. R. Reorg., 221 I. C. C. 15,26 (1937);.cf. Missouri P. R. R. Reorg., 239 I. C. C. 7, 120 (1940). There has as yet been little litigation with respect to classification as such. Sce, bowever, J. P. Morgan \& Co. v. Missouri P. R. R., 85 F. (2d) 35I (C. C. A. 8 th, 1936), cert. denied, 299 U. S. 604 (1936). The more common problem is that of priority, particularly of unsecured claims destined to 2 precarious junior position unless some special equity or statutory right to 2 preferred status can be established. Disputes frequenly arise as to the relative priority of tax and other governmental claims, In re Denver \& R. G. W. R. Co., 27 F. Supp. 983 (D. Colo. 1939); In re Chicago, M., St. P. \& P. R. R., 27 F. Supp. 685 (N. D. Ill. 1939), of claims alleged to fall within the "six-months sule," In re Chicago \& N. W. Ry., 110 F. (2d) 425 (C. C. A. 7th, 1940), and of personal injury claims of employces and others, In re New York, N. H. \& H. R. R., 92 F. (2d) 428 (C. C. A. 2d, 1937), cert. denied, 303 U. S. 650 (1938) (passenger); Thompson v. Glover, 94 F. (2d) 544 (C. C. A. 8th, 1938) (passenger); Central Hanover Bk. \& Trust Co. v. Williams, 95 F. (2d) 210 (C. C. A. 8th, 1938) (employee); Thompson Y. Siratt, 95. F. (2d) 214 (C. C. A. 8th, 1938) (cmployee, "six-months" rule discussed). On the "six-months rule," see FitzGibbon, The Present Status of the Six Months Rule (1934) 34 Col: Lo. Rev. 230 (1.934); Finlettex, Banxruptcy Reorganizatjon (1939) 373-385.

Almost every plan report of the Commissiun under $\$ 77$ has provided for cither payment in cash or assumption by the new company and payment in the ordinary course of business of claims found prior to secured claims, including reorganization and trustees' expenses, taxes, "six-months" claims, and claims. based on trustees' certificates secured by 2 prior lien. Claims assumed have kept their selative priority. See, e.g., Denver \& R. G. W. R. R. Reorg., 233 1. C. C. 515,588 (1939). In Chicago S. S. \& S. B. R. R. Reorg., 212 I. C. C. 547,565 (1936), "six-months" claims were awarded only 5-year $5 \%$ notes.

${ }^{36}$ See Warner, Some Finencial and Esonomic Problems in Railroad Recapitalizations, infra, p. 438.

${ }^{22}$ Chirago G. W. R. R. Reorg., 228 I. C. C. 585 , 626-627 (1938); Chicago \& E. I. Ry. Reorg., 230 I. C. C. $199,231-234$ (1938).

st Erie R. R. Reorg., Fin. Doc. No. 11915 (April 6, 1940), mimoo. rep. at 124 . 
the Commission's proper refusal to sanction an unduly complicated capital structure. $^{\mathbf{8 3}}$ The Commission's policy has been, in general, to avoid both divisional liens and exaggerated stratification. Normally, the securities authorized in roorganization, to satisfy the claims of holders of the numerous divisional and system bonds, and various classes of unsecured claims and stock, consist of fixed-interest bonds, contingent-interest bonds, and preferred and common stock. ${ }^{34}$ The nature and amounts of these securities are determined largely by economic considerations, but also with some reference to the problem of distribution. ${ }^{85}$

The allocation of reorganization securities under the Commission's principle of ro0\% paper satisfaction creates little difficulty where the corporation has a capital structure in which securities are arranged in layers. The Chicago Great Western reorganization will serve as an example. ${ }^{36}$ Apart from equipment trusts, a small terminal mortgage, a divisional mortgage of nominal amount, and indebtedness to the Railroad Credit Corporation and the Reconstruction Finance Corporation, all to be assumed or paid, existing capitalization consisted of one issue of frst mortgage bonds and preferred and common stock. The capitalization approved consisted, in addition to securities which were to be assumed, of First Mortgage 4s, General Income Mortgage $4 \frac{1}{2} \mathrm{~s}, 5 \% \$ 5^{\circ}$ par preferred stock, and $\$ 5^{\circ}$ par corrimon stock. Over a third of the new First Mortgage $4 s$ were to be sold for cash. There were allocated to the existing bondholders the balance of the first mortgage bonds, all of the income bonds, all of the preferred stock and enough of the common stock so that each bondholder received $100 \%$ paper satisfaction for his claim, principal and interest. There remained common stock with total par value equal to approximately one fourth of the par value of the outstanding preferred. This was awarded to the preferred stockholders, the common stockholders being excluded from the reorganization.

\section{Parallel Liens}

Simplicity of this sort, however, is far from typical of the major railroad reorganizations which have come before the Commission. In the Missouri Pecific case, the

s2 The Commission has been quite aware of this effect of its policy. See Chicago, M., St. P. \& P. R R Reorg., supra note 8, at 140; Missouri P. R. R. Reorg, 239 I. C. C. 7, 95 (1940).

"This general statement is, of course, subject to numcrous exceptions. Certain securities, Dotably equipment and terminal obligations, have usually been left undisturbed. Also certain types of new securities have been authorized in addition to those mentioned in the text. In the Missouri, Erie, New Haven and Chicago \& North Western proceedings collateral notes were provided, and, in the last, participating preferred stock and split-coupon bonds, the commutable interest becoming fixed if earned for a certain period. The most complicated financial structure authorized by the Commission was in the Missouri Pacific proceedings where, under the approved plan, the fixed-interest and income bonds and the preferred stock were each divided into two classes. In the following proceedings, the issue of warrants was approved. Erie R. R. Reorg., supra note 32, at II9; Akron C. \& Y. Ry. and Northern O. Ry. Reorg., 228 I. C. C. 645,673 (1938); Kansas City, K. V. and W. R. R. Reorg., 236 I. C. C. 137, 142 (1939). See, however, note 25, supra.

${ }^{28}$ Missouri P. R. R. Reorg., 239 1. C. C., 7, 108 (1940); New York, N. H. \& H. R. R. Reorg, supre note I4, at 107.

"Chicago G. W. R. R. Reorg., 228 I. C. C. 585 (r938); mod., 233 I. C. C. 63 (1939), confirmed, 29 F. Supp. 149 (N. D. Ill. 1939). For a helpful compilation of old and new or proposed capital structures of the major railroads in reorganization, see MCGinnis, Gutde to Defaulted Ranlxoad Bonde and Raiziond Reorganizatzon Securities (2d Issue, 1940). 
court had found that there were 55 different classes of creditors and stockholders. ${ }^{37}$. The difficulty, moreover, lies not in the mere number of classes, but in the fact that the secured creditors hold liens on different properties-what the Commission has. called "parallel liens." In cases of this sort, the allocation of the reorganization securities presents problems of a most complex and intriguing character.

An initial question is the legal problem of determining the property on which a particular class of securities has a prior claim. The procedure for handling this question has not been identical in the various reorganization proceedings. In some cases disputes as to liens have been largely fought out in and settled by the reorganization court before the Commission has issued its plan. ${ }^{38}$ In these, of course, the Commission has followed the court's decision. In other cases, however, there has been no judicial determination and the Commission has been required either to make a preliminary determination or to recognize the existence of doubts justifying some compromise.98

The Commission is then faced with the task of evaluating the properties subject to the respective liens, giving "due consideration to the earning power of the property, past, present, and prospective, and all other relevant facts." 10 The difficulty of this task is enhanced by the fact that normally no separate records as to the financial results of the operation of the various mortgage and leased line divisions have been kept.

A principal device used to ascertain the economic yalue of respective mortgage divisions has been the formula for scgregating revenues and expenses-a method which, indeed, is mentioned in the statute itself."1 In some cases, notably in the New Haven reorganization, the court has referred the terms of a proposed formula to the Commission pursuant to Section $77(\mathrm{c})(\mathrm{II}) .^{.2}$ In others, such as the Erie, the Chicago \& North Western, and the Frisco, a formula applied without Commission or court approval has been recognized by the Commission in its report on the plan.8

A segregation formula purports to show the earnings of each mortgage division as actually operated as part of the system. This may or may not be a fair basis for treatment in a reorganization plan. In some cases the earnings shown by such a

${ }^{27}$ Missouri P. R. R. Reorg., 239 I. C. C. 7, 28-32 (1940).

${ }^{38}$ In re New York, N. H. \& H. R. R., 27 F. Supp. 392 (D. Conn. 1938), af'd, 104 F. (2d) 1018 (C. C. A. 2d, I939); In re New York, S. \& W. R. R., 30 F. Supp. 257 (D. N. J. 1939); af'd as mod., 109 F. (2d) 988 (C. C. A. 3d, 1940), cert. denied, 6o Sup. Ct. 1075 (1940).

? Western Pac. P. R. Reorg., 230 I. C. C. 61, 97-r00 (1938) (Commission noted that its ruling was subject to final adjudication); Denver \& R. G. W. R. R. Reorg., 233 I. C. C. 515, 568-570 (r939); Chicago \& N. W. Ry. Reorg., 236 I. C. C. 575, 640 (x939); Chicago, M. St. P. \& P. R. R. Reorg., supra note 8, 2t 136-rist.

${ }^{10} \$ 77(\mathrm{c})$. Various problems of valuation under $\$ 77$ have been discussed at length in Spacth \& Windle, Valuation of Railroads under Section 77 of the Bankruptey Act (1938) 32 ILI. L. Rev. 517 and in 2 Bonbrugrt, The Valuation of Property (1937) 864 ff.

$4257(c)(10)$ and (II).

${ }^{2}$ New York, N. H. \& H. R. R. Reorg., 224 I. C. C. 723 (1938); Chicago, I. \& L. Ry. Reorg., 228 I. C. C. 209 (1938); New York, S. \& W. R. R. Reorg., 236 I. C. C. 425 (1939).

is In the Rock Island proceeding some aspects of the formula have been litigated in the courts without reference to the Commission. In re Chicago, R. I. \& P. Ry., ro8 F. (2d) 410 (C. C. A. 7th, 1939). For a brief discussion of the formula problem, see Meck \& Masten, Railroad Leases and Reorganization: I (1940) 49 YALE L. J. 626, 640 ff. 
study may be much more than the line could obtain except as part of the system, e.g., in the case of an alternate bridge line built to handle more economically traffic produced by other mortgage divisions. ${ }^{44}$ On the other hand, expenses of operating a line as part of a system may be greater than if the line were independently operated, ${ }^{45}$ and in almost all cases, the segregation formula will charge a division with certain expenses which would not be saved if the division were to be severed from the system.

In order to appraise possibilities such as these, studies are commonly prepared to show the gain or loss to the mortgage division and to the remainder of the system if the line were to be severed. While severance studies necessarily involve much in the way of assumption and estimate, particularly on matters such as the routing of traffic, and their results are thus markedly characterized by what Mr. Justice Holmes termed "a delusive exactness," 18 they haye often, and properly, been given weight by the Commission. ${ }^{47}$

Another type of study which has received consideration is the contributed traffic study. This consists of analyzing the amount of traffic originated and terminated by each mortgage division for the rest of the system. So far as concerns traffic which would be lost to the system if the mortgage division were to be severed, the considerations behind this are similar to those in the severance study. And as to traffic that would not be lost, there seems to be a belief that a line originating or terminating traffic is of superior stature to one that merely carries it-a recognition of the "business-getter."18 Objections have been made to studies of this type on the ground that the division originating or terminating traffic frequently does not itself either control or attract such traffic. In any event, such a study at least serves partially to compensate for the frequently inadequate terminal allowances in segregation formulas. 49

Other factors, such as traffic density and "strategic value," have also received some

\footnotetext{
"This apparently was the case as to several of the mortgage divisions in the Chicago \& North Western reorganization and as to the Erie \& Jersey and the Genesee River lines in the Erie reorganization. Compare the position of the Denver \& Salt Lake and the Denver \& Salt Lake Western in the Denver \& Rio Grande Western proceeding.

"Sec. e.g., the discussion of the Danbury \& Norwalk bonds in New York, N. H." \& H. R. R. Reorg,, supra note 14 , at $118-219$.

"Truax v. Corrigan, 257 U. S. 312, 343 (1921).

${ }^{\prime}$ See Chicago \& N. W. Ry. Reorg., 236 I. C. C. $575,632,641-642$ (1939); New York, N. H. \& H. R. R. Reorg., supra note I4, at II9; Erie R. R. Reorg,, supra note 32, at 116 . For a brief discussion of severance studies, see Meck \& Masten, supra note 43, at 645 ff.

"See, e.g., Missouri P. R. R. Reorg., 239 I. C. C. 7, 125 (1940); Denver \& R. G. W. R. R. Reorg., 233 I. C. C. 515,572 (1939).

i The diffeult question of what in a particular case is the terminal division and what is a proper allowance to it for its admittedly higher than road-haul expenses has been much litigated. New York, N. H. \& H. R. R. Reorg., 224 I. C. C. 723 (1938); N. Y., S. \& W. R. R. Reorg., 236 I. C. C. 425 (1940); Palmer v. Palmer, 104 F. (2d) I61 (C. C. A. 2d, r930), cert. denied, 6o Sup. Ct. 120, 121 (1939). What constructive mileage allowance, if any, should be awarded the Dotsero cut-off has been 2 central problem in Denver \& R. G. W. R. R. Reorg., 233 I. C. C. 515, 567-568 (1939). Commissioner Eastman, dissenting, decried the failure to make an allowance to the Old Colony for its heavy passenger terminal expenses, in New York, N. H. \& H. R. R. Reorg., supro note I4, $2 t$ I83 ff.
} 
recognition. ${ }^{30}$ While the data as to physical value are usually, if not always, mentioned, the regard which the Commission pays them is not altogether clear. 11.2

When a mortgage or leased line division's earnings, as developed by various studies, exceed the fixed charges on its divisional bonds, such excess earnings are customarily transferred to the next senior lien. ${ }^{53}$ On the other hand, where there is a deficit on a division subject to a divisional mortgage and one or more mortgages covering other properties as well, the question arises as to which, if any, of the junior liens shall be charged with this loss. A somewhat similar problem is presented where a branch subject to a system mortgage is operating at a loss. May the bondholders disclaim the branch line as security? Although these situations have existed in several cases, no settled principle seems to have been evolved.s

No uniform method has been or could be adopted for the translation of all these studies into an allocation of reorganization securities. Usually the Commission has leaned heavily upon allocations made in the plan filed by the debtor or in a plan filed by a group of institutional bondholders, making such adjustments as are required to adapt these to the somewhat contracted capital structure fixed by the Commission, or as are deemed appropriate in the light of the evidence adduced by other parties. ${ }^{55}$

\footnotetext{
${ }^{\text {so }}$ It has been stated that in determining the relative values of divisions "it is proper to consider the subjects of contributed traffic, strategic position and prospecrive earnings, or any other relevant factors. . . ." In re Chicago, R. I. \& P. Ry., 110 F. (2d) 395,399 (C. C. A. 7th, 1940). Weight was given to "strategic value" in New York, N. H. \& H. R. K. Reorge, supra note 14, at 118 (Boston \& N. Y. Air Line bonds) and $2 t$ 115-116 (Harlem River \& Pt. Chester bonds). See also Chicago, M., St. P. \& P. R. R. Reorg., satpra note 8, at 233 (Gen. Migs. bonds). Weight was given to adverse factors in id. at 73, 144-145 (Chicago, M. \& G. R. R. and Terre Haute bonds, but the treatment of the former later improved is id. (June 4, 1940), mimeo. rep. at 36-40).

61-s Compare, e.g., Chicago \& N. W. Ry. Reorg., 236 I. C. C. 575, 590, 635-636 (1939), with New York, N. H. \& H. R. R. Reorg., supra note I4, at I18. See St. Louis-S. F. Ry. Reorg., supra note I 4, at 44-45.

s2 Chicago, M., St. P. \& P. R. R. Roorg, supra note 8, at 131; Denver \& R. G. W. R. R. Reorg» 233 1. C. C. 515,570 (1939).

"Denver \& R. G. W. R. R. Reorg., 233 I. C. C. 515,572 (1939); New York, N. H. \& H. R. R. Reorg., supra note 14, 2t 19, 119-120; Chicago, M., Se P. \& P. R. R. Reorg., supra note 8, at 127-128, 137-138. Cf. St. Iouis-S. F. Ry. Reorg., supra note 14, at 64-65.

${ }_{53}$ The debtor mist file a plan. 577 (d). A plan may also be filed by the trustee or by other parties. 16id. In most proceedings involving major systems, including the Spokane International, Western Pacific, Denver \& Rio Grande, Chicago and Eastern Illinois, Chicago \& North Western, Missouri Pacific, Milwaukee, New Haven and Erie proceedings, 2 group of institutional bondholders bas intervened and filed 2 plas. Notably in the Chicago North Western proceedings, the Commission used the group plan as its starting point for many purposes, including the allocation of securitics. In the Ncw Haven case, the Commission followed more closely the debtor's allocations. The favorable recognition accorded plans filed by such groups is doubtless due in part to the fact that, as their interests are usually spread over the various bonds of the debtor, the framers of the plan have had every motive to make a fair allocation. It has been remarked that their active participation will do much to force "the practice to conform to the theory of priority" as laid down by the Supreme Court. Spacth \& Winks, The Boyd Case and Section 77 (1938) 32 In工. L. REv. 769, 770. A debtor's p!an frequently is dictated by a parent company secking primarily to preserve its own stock interest On the theory that debtors' plans have failed to be fair to all parties, it has been suggested to a Senate Committee that $\$ 77$ should be amended so as no longer to permit their filing. Additional Report of the Committee on Interstate Commerce Pursuant so S. Res. 71, 76th Cong., Ist Sess. (1939), Rep. No. 25, Pt 6, pp. 26-27. However, in the Chicago Great Western and Louisiana \& North West proceedings the debtor's was the only complete plan filed, and such 2 plan provided the basis for the Commission's report in the Chicago and Eastern Illinois proceeding where the group of institutions filed a plan of its own but later supported the debtor's amended plan.
} 
Perhaps the closest approach to adherence to a "scientific" method of distribution, at least so far as concerned the allotment of fixed-interest bonds, was in the New Haven reorganization. The starting point was the segregation formula which the Commission and the court had approved. ${ }^{30}$ This formula had been applied for the year ended May 31, 1937. The proportion of each division's earnings to those of the system, as determined by such application, was then applied, with appropriate adjustments, to the average earnings for the years 1933 -r $93^{8}$, inclusive. The result was termed the "adjusted segregated earnings" of each division. ${ }^{57}$ The plan provided that two small mortgages, each having an early maturity and secured by property having a value far in excess of the amount of the mortgage, one on an essential terminal property and the other with adjusted segregated earnings many times in excess of interest requirements, should be paid in cash. ${ }^{68}$ Three other issues, one a terminal mortgage, and two others with adjusted segregated earnings many times their interest requirements, were to be left undisturbed, with accrued interest to be paid in cash, since "it would appear inequitable to ask the holders of any of these bonds to exchange them for reorganization securities which admittedly would not be rated on the date of their issue as valuable as the bonds." proposed that existing bonds be allotted fixed-interest bonds to the extent that their adjusted segregated earnings covered interest charges 1.5 times, and this principle was generally applied by the Commission in dealing with the remaining bonds. ${ }^{60}$.

A more complicated method, putting greater stress on severance studies and attempting to take account of differences in the relative performance of particular mortgage divisions in good and bad years, was adopted by the committees representing life insurance companies and savings banks and largely approved by the Commission in the Chicago \& North Western reorganization.1 The committee's experts and the debtor had prepared segregation, severance and "contributive" income studies, on the basis of which the committee's experts had arrived at a "final measure of earnings." In the case of five bridge lines which had been built for the purpose of reducing operating costs by diverting traffic from existing routes, the severance studies were used as the "final measure of earnings." which originated and terminated a substantial proportion of traffic and also handled some bridge traffic, a weight of approximately two was given to the segregation study and a weight of one to the severance studies. ${ }^{63}$ All these studies were made for the year 1936. However, it was found that, during depression years, the earning power of the bridge lines was relatively greater than that of one of the system mortgages,

\footnotetext{
- New York, N. H. \& H. R. R. Reorg, 224 I. C. C. 723 (1938); In re New York, N. H. \& H. R. R, Record, p. 4399 (D. Conn., 1938).

"New York, N. H. \& H. R. R. Reorg., supra note 14, at 109-110.

se Id. at 112-113.

"Id. 2 I I13-114. The Harlem River and Port Chester bonds were also left undisturbed with accrued interest to be satiffied, after application of deposited cash, by fixed-interest bonds. Id. at 115-116.

${ }^{10} I d$. at II4-120.

12 Chicago \& N. W. Ry. Reorg, 236 I. C. C. 575 (1939).

-see Life Insurance Group Committee and Mutual Savings Bank Group Committee Brief (July 14, 1938), Chicago \& N. W. Rg. Reorg., pp. 191-193.

"Id. at 193-194.
} 
and that as earnings increased, the earning power of the system mortgages increased reluively much faster than that of the bridge lines. Consequently, as a basis for the distribution of fixed-interest bonds, on which interest is payable even in times of severe depression, an estimate was made as to the "final measure of earnings" for an average depression year. On the other hand, the allocation of income bonds was based upon an estimate of the "final measure of earnings" for a normal prospective year. The Commission followed the former method so far as concerned the splitcoupon bonds which it authorized; but whereas the committees, after distributing fixed-interest and income bonds, had allocated preferred stock to fill out $100 \%$ principal and interest of all mortgage claims and had allotted common stock in partial compensation to the bondholders for the loss of rights to income by acceptance for a part of their debt of income bonds and preferred stock which were not fully cumulative, the Commission eliminated this last-mentioned allotment, and allocated income bonds and preferred and common stock on the basis of the committec's allocation of income bonds and preferred stock, with various minor adjustments. ${ }^{.4}$

Another method of allocation, followed notably in the Erie and Missouri Pacific reorganizations and to some extent in the Milwaukee proceeding, might be termed the method of comparison. The report in the Erie reorganization will serve as an example. The debtor and an institutional group proposed plans both of which provided that the Prior-Lien bonds, which were secured by the Erie's Consolidated Mortgage, should receive 100\% of principal and accrued interest in new FirstMortgage fixed-interest bonds. This was supported by analyses of the valuation and earnings data concerning the property subject to the Consolidated Mortgage and was adopted by the Commission. The General-Lien bonds were also secured by the Consolidated Mortgage, but in subordination to the Prior-Lien bonds. However, the value of the security was deemed by the Commission to be sufficient to entitle the General-Lien bonds to share to the extent of $22.5 \%$ of their claim in the new fixedinterest bonds. ${ }^{65}$ The balance of their allotment was in income bonds and preferred stock. The Erie \& Jersey and Genesee River divisional bonds claimed a right to better treatment than the Prior-Lien bonds. After comparison of the three issues, the claim was denied in respect of the Erie \& Jersey bonds; but granted, to the extent of allowing a higher interest rate, in respect of the Genesee River bonds. The Convertible bonds stood apart because of the special nature of their collateral security, which consisted principally of stock in an anthracite coal company and an anthracite carrying branch line. Its value was examined, and treatment deemed appropriate was accorded. The Refunding and Improvement bonds were secured by the pledge of substantial amounts of General-Lien and Convertible bonds, by certain additional collateral security, and by a junior lien on the bulk of the system. The Commission awarded them the fixed-interest bonds, income bonds and preferred stock issuable in respect of the collateral, and allotted common stock for the remainder of the claim.

"Id. at 196-200; Chicago \& N. W. Ry. Reorg, 236 I. C. C. $575,632-636$ (1939). Ste also note 22, supra.

"A striking example of the consequences of the principle of roo\% paper satisfaction. 
However, the Refunding and Improvement bonds were allowed to take this stock at $\$ 37.17$ per share as against $\$ 40$ per share in the case of unsecured creditors-thus recognizing some value in the junior lien position. ${ }^{\text {be }}$

Special problems have arisen as to the treatment of strong underlying divisional issues. Occasionally the Commission has authorized the satisfaction of such issues by payment in cash. ${ }^{67}$ We have already referred to the Commission's statement in the New Haven proceeding, that the position of certain divisional issues was so strong that the bondholders could not be compensated even by $100 \%$ in new system first-mortgage bonds, and that fairness required that the issues remain undisturbed. ${ }^{\text {s }}$ The Chicago \& North Western reorganization plan provided that the Sioux City and Pacific ist $3 \frac{1}{2}$ s of 1936 and the Des Plaines Valley 1 st $4 \frac{1}{2}$ s of 1947 be exchanged for new $4 \%$ divisional bonds due in 1969 whereas the best security issued to other bondholders was a general mortgage bond due in 1989 with $21 / 2 \%$ fixed interest and an additional $1 \frac{1}{2} \%$ interest which should become fixed when the commutable interest had been earned and payable. for three successive years. ${ }^{69} \mathrm{~A}$ different expedient employed in the Missouri Pacific reorganization, which had the advantage of avoiding the perpetuation of divisional liens, was the issue of short-term collateral notes secured by pledge of first-mortgage bonds and to bear such interest as to permit them to sell at par. ${ }^{70}$

In other cases, however, apparently strong divisional liens have not fared so well. In the Denver \& Rio Grande Western proceeding, although the evidence showedthat the earnings of the Denver's western lines were more than adequate to cover interest charges on the bonds representing first liens on such lines, the Commission not only rejected suggestions of a separate western-division mortgage and of a special series of short-term fixed-interest bonds with an interest rate and other features intended to insure their selling at par, but allotted no fixed-interest bonds at all. ${ }^{71}$ The Commission justified this treatment on the grounds that all the permissible fixed-interest bonds were required to be issued to provide new money for the payment of trustees' certificates and reorganization expenses and redemption of the FirstMortgage bonds of the Denver \& Salt Lake and to provide satisfaction in full for the notes held by the R. F. C. The Commission stated:7?

The approval of the issue of new first-mortgage bonds to the Finance Corporation, while the debtor's bondholders are to receive none of such bonds, is justified, in our opin-

es Erie R. R. Reorg, supra note 32, $2 t$ 108-117, 140.

${ }^{\circ 7}$ E.g., Evansville Belt rst 5's of 1940 in Chicago \& E. I. Ry. Reorg., 230 I. C. C. 571, 573 (1939); N. Y. \& Erie 2d and $3 d$ mtge. bonds in Erie R. R. Reorg, supra note 32, at $119 ;$ and N. Y. \& New England-Boston Terminal bonds and Dutchess County bonds in New York, N. H. \& H. R. R. Reorg., supra note 14 at 1r2-113. Compare the treatment of Mason City \& Fort Dodge bonds in Chicago G. W. R. R. Reorg., 233 I. C. C. 63,68 (1939).

${ }^{8} \mathrm{New}$ York, Providence \& Boston, the Naugatuck, and the Providence Terminal bonds. New York, N. H. \& H. R. R. Reorg., supra note 14, at II3-14. See also the treatment of The Harlem River and Port Chester bonds. Id. at I15-116.

"Chicago \& N. W. Ry. Reorg., 236 I. C. C. 575, 633, 647-649 (1939).

${ }^{70}$ Missouri P. R. R. Reorg., 239 I. C. C. 7, $101-102$ (1940):

${ }^{72}$ Denver \& R. G. W. R. R. Reorg, 233 I. C. C. $515,574-575$ (1939).

"Id. at 576 . 
ion, by considerations beyond the estimated value of the particular securities under pledge. Not only is the Finance Corporation in possession of the stocks of the Salt Lake and the Salt Lake Western, and thus in position to veto the consolidation of properties which forms the basis of the plan, but it has indicated that it will, if satisfied with the plan, agree to underwrite the financing necessary to redeem the Salt Lake bonds outstanding in the hands of the public, the payment of trustee's certificates, and the cash required for reorganization expenses, etc., a total of $\$ 17,443,675$.

Again, in the Milwaukee reorganization, the Commission awarded the Milwaukee \& Northern Ist $4 \frac{1}{2}$ s only $70 \%$ in First Mortgage $4 \%$ bonds and $30 \%$ in General Mortgage $4 \frac{1}{2} \%$ income bonds, although interest in 1936 was estimated to have been earned about four times on one theory and about three times on another, and testimony had been introduced to show that the Northern could operate successfully as an independent road or in association with some other system. ${ }^{78}$ The unexpressed reason behind this was, of course, that the amount of available fixedinterest bonds was so small that the existing Milwaukee General Mortgage bonds, secured by a first lien on over 6,000 miles of lines east of the Missouri River and which had passed unscathed through the 1927 reorganization, could be given only $25 \%$ in that type of security. Hard cases mean hard treatment even for strong divisional issues.

While the "value" of the particular property subject to the mortgage is given great weight in determining the amount and type of reorganization securities to be exchanged for existing bonds, the Commission does not appear to have been very much concerned with changes in lien position for the future. For example, in the Erie reorganization, the Prior-Lien bonds were obliged to share the new first mortgage, to the extent of nearly $50 \%$, with divisional and junior issues. ${ }^{74}$ Nicety in the preservation of lien position becomes impracticable in the light of the Commission's principles of paper satisfaction and its. aversion to undue complication of the financial structure. Substantially no weight appears to have been given to differences in existing coupon rates. ${ }^{7 x^{2}}$

\footnotetext{
${ }^{12}$ Chicago, M. St. P. \& P. R. Co. Reorg., supra note 8, at 129-131. In spite of this treatment of the xst 4 $1 / 2$ 's, the Consolidated Mortgage bonds of the Milwaukee \& Northern, whose main value from the standpoint of earnings was in their second lien on the same property, reecived $25 \%$ in new fixed-interest bonds.

${ }^{74}$ In only a few instances has the Commission sought to explain the compensation given or reparation required because of changed lien treatment. Chicago G. W. R. R. Reorg., 228 I. C. C. 585, 623 (1938); New York, N. H. \& H. R. R. Reorg., supra note 14, at 134-135; Erie R. R. Reorg., supra note 32, at 108-IIr; Missouri P. R. R. Reorg., Fin. Doc. No. 9918 (April 9, 1940), mimeo. rep. at 22-23.

rea See, e.g., Chicago \& N. W. Ry. Reorg., 236 I. C. C. 575, 636-637 (1939) (general mortgage bonds bearing $3 \frac{1}{2}, 4,4 \frac{1}{2}, 4 \%$ and $5 \%$ interest given like treatment); New York, N. H. \& H. R. R. Reorg, supra note 14, at 116-118 (New England mortgage bonds bearing 4 and $5 \%$ interest given like treatment). The frequent lack of discussion of.changes in rates of interest in the Commission's current reports contrasts sharply with the emphasis placed on relative income position in Bonbright \& Bergerman, Two Rival Theories of Priority Rights (1928) 28 Cor. L. Rev. 127. See 2 Bonbractr, The Valdation or Property (x937) 867-868, for a re-examination of the author's earlier views concerning the "relative" priority theory. Cf. St. Louis-S. F. Ry. Reorg., supre note 14, at 81-83.
} 


\section{Claims Secured by Collateral}

Special problems have arisen in the case of claims secured by collateral. These claims fall into two general classes-collateral trust bond issues, and collateral loans by commercial banks, the Railroad Credit Corporation, and the Reconstruction Finance Corporation.

Collateral trust bond issues can likewise be roughly divided into two categories. In one class, the bonds are secured in part by the pledge of a smaller face amount of senior securities and in part by a junior mortgage lien. Here, the usual treatment has been to allot the reorganization securities that would have been issuable in respect of the pledged collateral, and to fill out the $100 \%$ paper satisfaction with some type of junior security. ${ }^{75}$ In the other class the bonds are secured only by pledge of a larger face amount of system securities. A good instance is found in the New Haven reorganization, where $\$ 15,302,600$ principal amount of Fifteen-Year $6 \%$ Secured Gold Bonds were secured by pledge of $\$ 23,000,000$ principal amount of the Debtor's First and Refunding bonds. Although the principal and interest of the Secured 6s was only $\$ 18,516,146$, there would have been issuable for the pledged First and Refunding bonds, $\$ 5,635,000$, or $20 \%$ of principal and accrued interest, in fixed-interest bonds, $\$ 11,270,000$, or $40 \%$ of principal and accrued interest, in income bonds, and another $\$ 11,270,000$ in preferred stock, or a total of $\$ 28,175,000$. The Commission concluded that the inflation of the capital structure that would result from issuance of these securities would be undesirable, and that the holders of the Secured $6 s$ should be required to cut down their participation to the amount of their claim, being compensated by an appropriate increase in the proportion of higher grade securities. Since the fixed-interest and income bonds issuable in respect of the pledged collateral would alone have nearly equaled the amount of the claim, the solution had to take the form of eliminating preferred stock and increasing the proportion of fixedinterest bonds. In other words, the problem was to determine how $\$ 18,516,146$ must be divided as between fixed-interest and income bonds in order to produce a total value equal to the value of the $\$ 5,635,000$ in fixed-interest bonds, $\$ 11,270,000$ in income bonds, and $\$ 11,270,000$ in preferred stock that would have been issuable for the pledged collateral. Since the Commission found the evidence inadequate to permit such a determination, it cut the Gordian knot by raising the proportion of the fixed-interest bonds to be issued in respect of the pledged bonds in the same ratio as the amount of the collateral bore to the debt. That is, since the debt was secured by approximately $\mathrm{I}^{1 / 2}$ times its face amount in pledged bonds, the proportion of fixed-interest bonds issuable in respect of the pledged bonds was made $30 \%$ instead of the $20 \%$ applicable in the case of bonds publicly held. This resulted in the issuance of $\$ 8,452,500$ of fixed-interest bonds, or slightly more than $45 \%$ of the debt, and the balance was made up by income bonds. ${ }^{76}$ Similar treatment was accorded a number

\footnotetext{
T" As in Erie R. R. Reorg., supra note 32, at 116 (Refunding and Improvement bonds).

${ }^{20} \mathrm{New}$ York, N. H. \& H. R. R. Reorg, supra note 14, at 120-122.
} 
of the bank creditors. ${ }^{77}$ While the method was admittedly illogieal, it seems reasonably clear that the collateral bondholders were not unfairly treated. This example also serves to illustrate why many plans have proposed to limit the ratio in which the reorganized company may pledge its bonds.

The treatment of collateral loans made by commercial banks, the Railroad Credit Corporation, and the Reconstruction Finance Corporation has, of course, varied in accordance with the nature, amount and value of the collateral. In some cases the sheer amount of the collateral has been such that the Commission has awarded payment in cash. Thus, in the Chicago Great Western reorganization, it was found that, on the basis of the par value of existing bonds held by each, the claim of the R. F. C., principal and interest, was covered 3.28 times and that of the R. C. C, principal and interest, 3.67 times, whereas that of existing bondholders was secured only .87 times due to the accumulated interest: Accordingly, the Commission held that full cash payment should be made to the R.F.C. and the R. C. C. ${ }^{78}$ The collateral position of the banks and the R. C. C. in the Erie reorganization was likewise deemed to justify full payment in cash. ${ }^{79}$ This does not seem to have been as clear as the Commission assumed, at least so far as the R. C. C. was concerned. Although the R.C. C.'s collateral would have entitled it to reorgarization securities greatly in excess of the face amount of its claim, this excess would have consisted almost wholly of common stock. In other words, while the money to pay the R. C. C. will come from the sale of collateral-trust notes secured by a pledge of securities of the same issue as those awarded senior creditors, the benefit of retirement of the loan will inure chiefly to junior creditors and stockholders.

Another situation presented is where a note is secured by salable non-system collateral. In one case where this had a market value at least approximating the face of the note, but the company's finances were not such as to justify cash payment and the sale of the collateral would have been inadvisable from its standpoint, the Commission approved the issuance of new short-term notes secured by the existing collateral.80 In another case non-system collateral, which was only part of the security, was ordered sold, the proceeds to be applied in reduction of the debt.12

A somewhat different problem is presented where the R.F. $C_{n}$ as a condition to agreeing to finance a reorganization, has insisted upon better treatment of its claims than that to which it would otherwise have been entitled. This is reminiscent of the old equity receivership problem as to the extent to which the value of securities offered to stockholders might exceed the amount of the new money to be paid. We have already referred to the Denver \& Rio Grande Western proceeding, where the allocation of first-mortgage bonds to the R. F. C. in satisfaction of its existing claim

I7 Id. at 125 - 226 .

${ }^{78}$ Chicago G. W. R. R. Reorg, 228 I. C. C. 585,617 (1938).

"Erie R. R. Reorg., supra note 32, at 118.

${ }^{80}$ New York, N. H. \& H. R. R. Reorg., supra note 14 , at 122-124 (chaims of the R. C. C. and the R. F. C.). The I. C. C. rejected as not "fair and equitable" the debtor's proposal that they merely be awarded fixed-interest bonds.

${ }_{81}$ Chicago \& N. W. Ry. Reorg., 236 I. C. C. 575,631 (1939). 
prevented the making of any such allocation to divisional bends that were earning their interest. ${ }^{82}$ In the $W$ estern Pacific reorganization, on rehearing, the Commission awarded to the notes held by the R. F. C., which were secured for the most part by junior securities, the same treatment as First Mortgage bonds in consideration of (1) the purchase of the new first-mortgage bonds by the R. F. C. at par and (2) the value of the collateral securing the notes. 88

Opinions will differ as to the propriety of this practice. On the one hand, it can be said that the new bonds will not sell at par, and that even if they would, an investment banker would certainly require a commission for underwriting themif, indeed, an underwriting over so long a period as is involved in a reorganization under Section 77 could be obtained at all. Against this, it may be argued that the improved position which the R.F.C. is obtaining as to its existing claim may develop to be out of all proportion to a fair underwriting fee. ${ }^{84}$

We have endeavored to place the subject in its setting, to develop the principles applied by the Commission and the few courts that have rendered opinions, and to note the major problems that have arisen. More than that has been impossible here. If the Rule in Shelley's Case can not be kept in a nutshell, it is equally impossible to discuss critically, within decent limits, the complex problems of distribution in railroad reorganizations of the last decade.

Opinions will differ as to the propriety of the treatment meted out by the Commission in a particular case or to a particular security. Where sacrifices are being parceled out, enthusiasm is not likely over the results. Yet a study of the Commission's reports gives a definite impression of a sincere, painstaking, and, in most cases, successful effort to unravel the tangled skeins and to reach a fair result. Certainly the Commission's decisions of the last few years constitute a most important case-book for the student of reorganization law.

\footnotetext{
see p. 433, supra.

"Western Pac. R. R. Reorg., 233 1. C. C. 409, 4r4 (1939).

"It is one thing to permit preferred treatment to be given to loans made in the past, where the lender demands such treatment as a condition to supplying new money unavailable from any other source. In the Frisco reorganization, the Commission went much further. There, although no new money was required, the Conmission recognized "special equities" in the paition of tho R. F. C. and the R. C. C. as to loans made in seeking to avert receivership. St. Louis-S. F. Ry. Reorg, suprs note 14, at 48-59.

In contrast to this favorable treatment received by the R. F. C. is the Commission's refusal in another case to order payment as part of the reorganization of the amount due on trustees' certificates although such payment was in accordance with the conditions of the R. F. C.'s tentative commitment to finance in part the cash offers of the debtor's plan. Akron, C. \& Y. Ry. and Northern O. Ry. Reorg., 228 I. C. C. $645,667-670$ (1938). In the Savannah \& Atlanta proceeding one of the chief problems was whether the Piedmont Company, owner of all the common stock, over $61 \%$ of the preferred stock and about $41 \%$ of the bonds, and proponent of the only plan filed, was entitled, as proposed in the plan, to receire all the new common in exchange for the new preferred allocable to it as 2 creditor and also the conveyance of a valuable waterfront tract. Although the Commission disagreed with the logic of this plan, it did not dispute its fairness and declined to interfere with the "business judgment" of the partics. Savannah \& Atlanta Ry. Reorg., 224 I. C. C. 197, 213 (1937). Cf. British America Nickel Corp. Itd. v. M. J. O'Brien, Ltd. [rg27] A. C. 369 .
} 